\title{
Microneedle: Teknologi Baru Penghantar Vaksin COVID-19
}

\author{
Amilia Shafa*1, Sriwidodo² \\ ${ }^{1}$ Program Studi Sarjana, Fakultas Farmasi, Universitas Padjadjaran \\ ${ }^{2}$ Departemen Farmasetika dan Teknologi Farmasi, Fakultas Farmasi, Universitas Padjadjaran \\ Jl. Raya Bandung, Sumedang Km 21 Jatinangor, 45363 \\ *E-mail: amiliashafa@gmail.com \\ (Submit 17/6/2020, Revisi 12/10/2020, Diterima 12/10/2020)
}

\begin{abstract}
Abstrak
Wabah COVID-19 telah menyebar lebih dari 200 negara dan menjadi perhatian kesehatan di seluruh dunia. SARS-CoV-2 adalah virus penyebab COVID-19 berasal dari keluarga coronaviridae. Virus tersebut memiliki kesamaan genom dengan SARSCoV dan MERS-CoV. Pencegahan penyakit terutama yang disebabkan oleh virus seperti COVID-19 dapat dilakukan dengan vaksinasi. Sebagian besar pemberian vaksin menggunakan jarum konvensional, jarum hipodermik, yang tidak bisa digunakan dengan mudah oleh pasien. Selain itu, penggunaan jarum hipodermik dapat menimbulkan rasa sakit. Maka, jarum dibentuk dengan ukuran mikron, sehingga penetrasinya tidak mencapai ujung saraf yang peka terhadap nyeri. Microneedle dapat digunakan sendiri tanpa rasa sakit dan melalui mekanisme stress mekanikal dari microneedle dapat digunakan sebagai adjuvant dalam meningkatkan respon imun. Microneedle merupakan teknologi vaksinasi baru yang aman dan memberikan kekebalan protektif terhadap serangan virus COVID-19. Termostabil yang diberikan oleh microneedle dapat mengurangi penggunaan pendingin, sehingga mengurangi biaya produksi dan meningkatkan kemudahan dalam pendistribusiannya. Berdasarkan fiturfitur tersebut, microneedle memiliki potensi untuk digunakan sebagai penghantar vaksin yang efektif dalam mencegah penyebaran virus COVID-19.
\end{abstract}

Kata kunci: microneedle, coronavirus, vaksin, COVID-19.

\section{Pendahuluan}

Pemerintah Cina pada tanggal 31 Desember 2019 mengumumkan beberapa kasus pneumonia yang tidak diketahui etiologinya di Wuhan. Penderita melaporkan bahwa gejala yang dialami berupa demam, batuk kering, kesulitan bernapas, dan sakit kepala. Wabah ini pertama kali dilaporkan berasal dari paparan di pasar lokal seafood Wuhan. Sebagian besar pada kasus awal, penderita memiliki riwayat kontak dengan pedagang atau orang-orang yang berada di pasar seafood tersebut. ${ }^{1,2}$ 
Pada 9 januari 2020, Pusat Pengendalian dan Pencegahan Penyakit Cina (CCDC) melaporkan bahwa novel coronavirus merupakan agen penyebab kasus ini. Kemudian, virus ini diisolasi dan diteliti urutan gennya. Virus tersebut dinamai SARS-CoV-2 yang memiliki kesamaan genom dengan SARS-CoV dan MERS-CoV. WHO menamai penyakit tersebut dengan sebutan COVID-19 (Coronavirus Disease 2019) yang disebabkan oleh virus corona baru. Lebih dari 200 negara telah terpapar oleh wabah ini dan cukup sulit untuk mengendalikannya. ${ }^{2,3}$

Sebelum terjadi pandemi COVID-19, virus corona telah menyebabkan endemi termasuk SARS (severe acute respiratory syndrom) dan MERS (middle east respiratory syndrom). SARS-CoV penyebab endemi yang terjadi di tahun 2003. Virus tersebut berasal dari daerah cina bagian selatan. Sedangkan MERS terjadi pertama pada tahun 2012 di Arab Saudi. Endemi tersebut kemudian menyebar ke beberapa negara. Kedua virus tersebut termasuk ke dalam keluarga coronaviridae genus betacoronavirus. ${ }^{4}$

Pencegahan penyakit terutama yang disebabkan oleh virus seperti COVID-19 dapat dilakukan dengan vaksinasi. Sebagian besar bioterapi dan vaksin diberikan secara injeksi subkutan atau intramuskular. Penggunaan jarum suntik tidak dapat dengan mudah digunakan sendiri oleh pasien di rumah. Selain itu, penggunaannya menimbulkan rasa sakit yang tidak nyaman bagi pasien. Jarum suntik yang dipakai ulang dapat menyebarkan patogen melalui peredaran darah. ${ }^{5}$ Pemberian bioterapetik dan vaksin melalui rute pemberian oral menunjukkan hasil yang kurang efektif. Sebagian obat tidak dapat diabsorbsi dan terjadi degradasi di saluran cerna. Rute pemberian yang lainnya pun menunjukkan hasil yang kurang efektif dibandingkan injeksi dengan jarum suntik. ${ }^{6}$

Dalam mengatasi hal tersebut, maka jarum dibentuk dengan ukuran mikron (microneedle) untuk meningkatkan penghantaran bioterapetik, keamanan, dan kepatuhan pasien. Microneedle dapat menghantarkan partikel kecil tanpa memberikan rasa sakit. Sehingga efektivitas vaksin meningkat dan dosis yang dibutuhkan tidak terlalu besar. ${ }^{5,7,8}$ Perbandingan ukuran dan tingkat penetrasi antara microneedle dengan jarum konvensional ditunjukkan oleh gambar 1 .

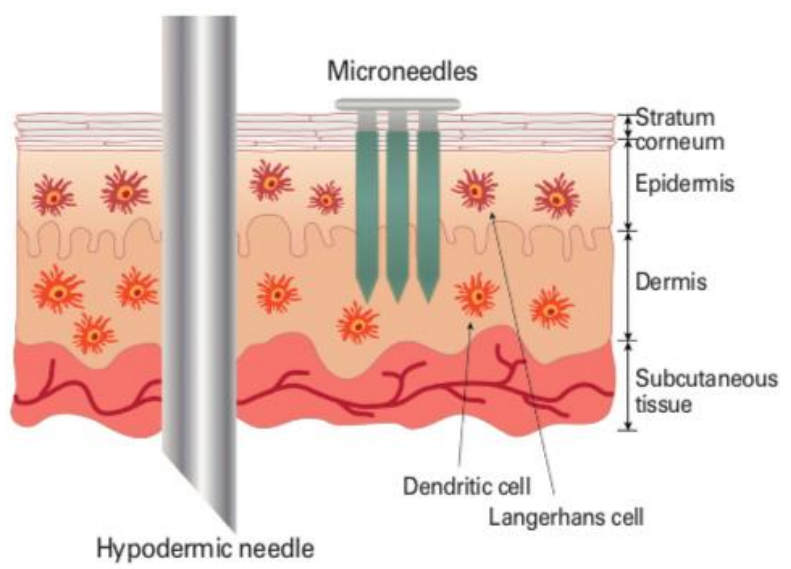

Gambar 1. Perbandingan jarum suntik konvensional dengan microneedle. ${ }^{9}$ 
Berdasarkan data dan pengetahuan tentang microneedle, review artikel ini diharapkan dapat memberikan gambaran mengenai penggunaan microneedle sebagai penghantar vaksin COVID-19. Wawasan tersebut dapat membantu dalam merancang vaksin atau terapi COVID-19 yang efektif dan efisien.

\section{Metode}

Metode yang digunakan dalam article review ini adalah dengan studi pustaka dengan mencari jurnal-jurnal pada situs jurnal internasional dengan kata kunci "Fabrication of microneedle", "microneedle for vaccine delivery", "Covid-19 outbreaks", "SARS-CoV vaccines" dan "MERS-CoV vaccines". Sumber lainnya diambil dari situs CDC. Kriteria inklusi meliputi jurnal yang diterbitkan 10 tahun terakhir.

\section{Hasil dan Pembahasan}

\section{Karakteristik Virus Corona}

Virus corona, termasuk ke dalam keluarga coronaviridae, merupakan virus RNA positive-sense rantai tunggal yang dapat menyebabkan infeksi pernapasan dan saluran cerna pada binatang. Virus ini dibagi ke dalam empat jenis berdasarkan hubungan filogenik dan kesamaan struktur, yaitu alfacoronavirus, betacoronavirus, gammacoronavirus, dan deltacoronavirus. Alfacoronavirus dan betacoronavirus menginfeksi mamalia, terutama kelelawar, sedangkan gammacoronavirus dan deltacoronavirus sebagian besar menginfeksi burung. ${ }^{10}$

Kemampuan rekombinasi dan tingkat mutasi yang tinggi pada virus RNA, memungkinkan virus jenis ini dapat beradaptasi dengan lingkungan dan kondisi inang yang baru. Hal ini yang membuat virus corona dapat berpindah dari binatang dan menginfeksi manusia. ${ }^{10}$ Corona virus yang menginfeksi manusia pertama kali diidentifikasi pada tahun 1960. Terdapat tujuh spesies virus corona yang menginfeksi manusia, yaitu HCoV-229E dan HCoV-NL63 berasal dari jenis alfacoronavirus, HCoVOC43 dan CoV-HKU1 jenis betacoronavirus. Virus tersebut menyebabkan infeksi saluran napas atas ringan pada inang imunokompeten, walaupun dapat menyebabkan infeksi parah pada geriatri dan pediatri. Tiga virus dari jenis betacoronavirus yang menyebabkan infeksi saluran napas parah pada manusia yaitu SARS-CoV, MERS-CoV, dan SARS-CoV-2 - penyebab COVID-19. ${ }^{11,12}$

\section{Struktur SARS-CoV-2}

Virus corona memiliki spike glycoprotein, protein $\mathrm{S}$, yang terdapat pada permukaan yang menyelubunginya. Protein $S$ bertanggung jawab dalam ikatan dengan reseptor dan fusi membran. ${ }^{13}$ 
Struktur SARS-CoV-2 secara genomik memiliki kemiripan dengan SARS-CoV, penyebab severe acute respiratory syndrom pada tahun 2002, dibandingkan dengan Middle East respiratory syndrome - Coronavirus (MERS-CoV). Kemiripan tersebut secara genetik dilihat dari protein struktural (Spike, Envelope, Membrane, Nucleocapsid). Hal ini yang menyebabkan SARS-CoV-2 memiliki mekanisme yang sama dengan SARS-CoV, yaitu ikatan terhadap reseptor ACE2 pada permukaan sel manusia. ${ }^{4}$ Sedangkan MERS-CoV berikatan dengan reseptor dipeptydile peptidase 4 (DDP4). ${ }^{13}$

Mekanisme ikatan terhadap reseptor dan fusi membran, baik SARS-CoV-2 dan MERS$\mathrm{CoV}$, melalui receptor-binding domain (RBD) pada $\mathrm{N}$-terminal di permukaan subunit (S1) dan kemudian fusi membran dengan C-terminal transmembran (S2). Protein S tersebut merupakan target yang baik dalam pengembangan vaksin. ${ }^{14}$

\section{Vaksinasi dengan Metode Konvensional}

Sebagian besar vaksin diberikan secara injeksi subkutan atau intramuskular. Penggunaan injeksi dengan jarum hipodermik dapat menghantarkan berbagai tipe molekul vaksin secara langsung dan cepat ke dalam tubuh. Injeksi juga dapat meningkatkan efektivitas dibandingkan dengan rute pemberian oral karena sebagian besar vaksin tidak dapat diabsorbsi dengan baik di saluran cerna. Selain itu, dapat menghindari kerusakan bioterapetik oleh enzim atau cairan yang disekresikan pada saluran cerna. ${ }^{5,6}$

Pemberian vaksin dengan injeksi diperlukan keahlian dan tidak dapat digunakan secara mandiri oleh pasien. Penggunaan jarum hipodermik memberikan rasa sakit yang kurang nyaman bagi pasien dan juga memberikan risiko penyebaran patogen secara sistemik. Banyak pasien yang mengalami fobia jarum, terutama pada pasien anak-anak. Kondisi tersebut menggambarkan kecemasan terkait dengan jarum atau penggunaan rute pemberian dengan injeksi. ${ }^{15}$

\section{Microneedle}

Microneedle, sama seperti namanya, adalah jarum yang dibentuk dalam ukuran mikron dengan formulasi obat. Formula tersebut dapat langsung menembus lapisan stratum korneum pada kulit. Bentuk jarumnya yang kecil, memungkinkan penetrasi microneedle tanpa memberikan rasa sakit karena jarum tersebut tidak mencapai ujung saraf, peka terhadap nyeri, yang terdapat pada lapisan dermis. ${ }^{16}$ 
Kelebihan dari penggunaan microneedle dalam penghantaran obat dan vaksin adalah: ${ }^{17}$

- Dapat menghantarkan molekul dalam bentuk yang lebih besar dibandingkan dengan rute pemberian injeksi lainnya.

- Administrasi bahan aktif obat yang tidak menimbulkan rasa sakit.

- Proses pemulihan pada situs penetrasi lebih cepat dibandingkan dengan jarum konvensional.

- Mempermudah dalam administrasi bahan aktif obat atau vaksin.

- Tidak mengalami first-past metabolism.

- Miminimalisir infeksi mikroba.

- Laju penghantaran obat dapat dikontrol lebih efektif dibandingkan dengan penghantaran obat melalui stratum korneum.

- Target penghantaran obat pada area yang diinginkan.

- Meningkatkan efikasi obat sehingga dapat mengurangi dosis.

Adapun kekurangan dari microneedle adalah: ${ }^{17}$

- Kurangnya akurasi dosis dibandingkan dengan jarum konvensional.

- Memungkinkan terjadinya partikel yang keluar dari permukaan kulit dan jarum dapat menembus kulit dengan derajat yang berbeda apabila microneedle tidak digunakan dengan benar.

- Penghantaran obat dapat dipengaruhi oleh faktor eksternal, seperti tingkat hidrasi kulit.

- Terdapat variasi kedalaman penetrasi karena tiap individu memiliki ketebalan stratum korneum yang berbeda.

- Penggunaan yang berulang di tempat yang sama dapat merusak pembuluh darah.

- Bagian ujung dari microneedle dapat tertinggal pada kulit saat pelepasan patch.

Microneedle bedasarkan desain dan komposisinya terbagi menjadi empat jenis yaitu solid microneedle digunakan pada kulit sebelum pemberiam bahan bioaktif; coated microneedle untuk disolusi obat di kulit; dissolving microneedle bertujuan untuk memberikan pelepasan obat atau vaksin terkontrol menggunakan suatu polimer; dan hollow microneedle untuk injeksi. ${ }^{18,19}$ Skematika desain microneedle dalam penghantaran produk farmasetik dapat dilihat pada gambar 2 .

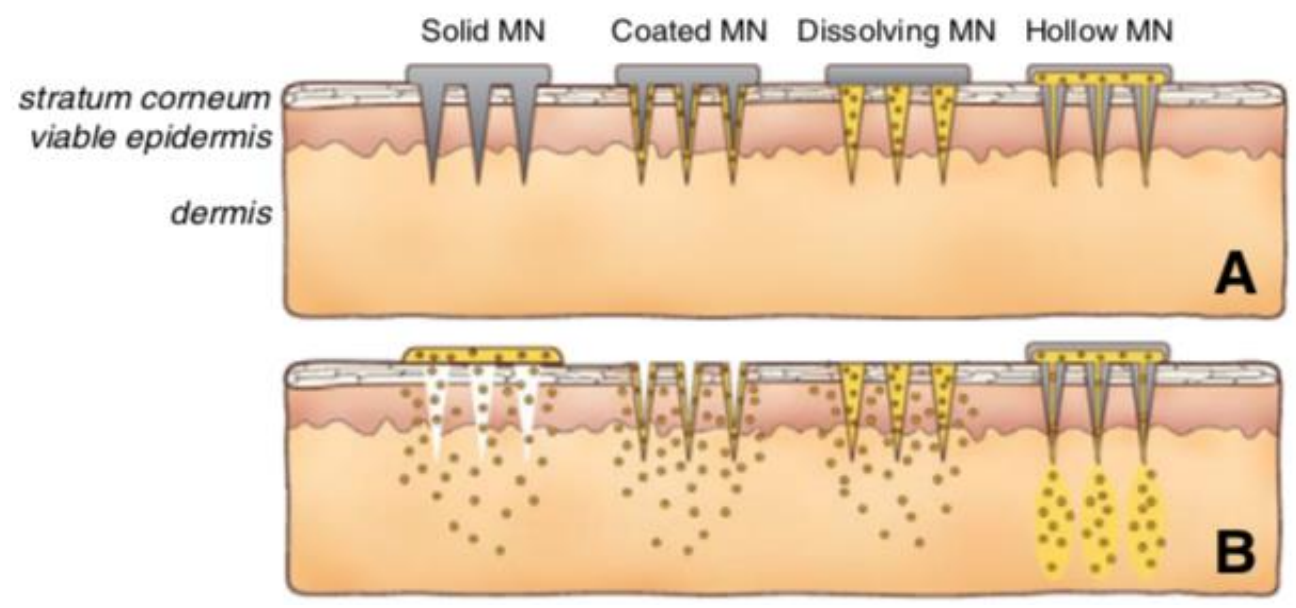

Gambar 2. (A) dan (B) Jenis-jenis microneedle yang diaplikasikan pada kulit ${ }^{5}$ 


\section{Solid microneedle}

Solid microneedle digunakan sebelum pengaplikasian produk farmasetik pada kulit dengan tujuan membentuk lubang atau kanal berukuran mikron pada kulit. Saat solid microneedle pada permukaan kulit, jarum-jarum berukuran mikron tersebut akan membentuk pori, lubang, berukuran mikron yang apabila obat dalam formulasi semi solida diaplikasikan, maka akan meningkatkan penetrasi obat. Pori yang terbentuk juga akan meningkatkan permeabilitas kulit. ${ }^{16}$

Selain obat atau kosmetik, solid microneedle dapat digunakan untuk administrasi vaksin melalui kulit. Vaksin akan berdifusi pada kulit melalui pori-pori yang terbentuk. Aplikasi vaksin tersebut akan memberikan efek lokal pada kulit maupun efek sistemik. Vaksin yang telah dikembangkan dengan solid microneedle adalah difteri, influenza, malaria, dan hepatitis B. Vaksin tersebut telah diuji secara in vivo pada mencit. Adapun vaksin anthrax, diuji pada mencit dan kelinci, dan vaksin rabies, sudah diuji klinik pada manusia, telah dikembangkan menggunakan solid microneedle dalam sistem penghantarannya. ${ }^{20}$

Fokus dari solid microneedle adalah menyediakan kekuatan mekanik sehingga dapat membentuk kanal pada kulit dengan cara menajamkan bagian ujung jarum. Sehingga, pembuatan solid microneedle diperlukan pemilihan bahan dan bentuk geometri untuk mendukung penggunaannya. Bahan-bahan yang digunakan dalam pembuatan microneedle yaitu berasal dari silikon. Seiring berjalannya waktu, sekarang microneedle banyak dibuat dari logam, polimer, gelas dan keramik, dan bahan lainnya yang desesuaikan dengan tujuan dari penggunaan microneedle. ${ }^{5}$

\section{Coated microneedle}

Coated microneedle sama seperti solid microneedle, namun formula obat terdapat pada permukaan jarum (melapisi jarum). Pada coated microneedle diperlukan formulasi dengan viskositas dan tegangan permukaan yang sesuai untuk distribusi yang merata dari bahan obat yang melapisi permukaan microneedle. Formulasi coating yang larut air juga penting untuk kecepatan pelarutan obat saat penetrasi microneedle ke dalam kulit. ${ }^{18}$

Pada pembuatan coated microneedle, pelapisan microneedle dengan cara dipping (pencelupan) atau spraying (penyemprotan) bahan larut air yang diformulasikan untuk meningkatkan viskositas, sehingga dapat meningkatkan ketahanan formula pada microneedle. Formulanya terdiri atas surfaktan sebagai zat pembasah pada permukaan microneedle; obat, vaksin, atau bahan aktif lainnya; dan bahan penstabil untuk melindungi obat dari kerusakan saat pengeringan dan penyimpanan. ${ }^{5}$

Surfaktan yang dapat digunakan pada coated microneedle agen pembasan dan untuk meningkatkan persebaran bahan pada permukaan microneedle adalah tween 20, poloxamer 188, lutrol F-68 NF, dan quil-A. Thickening agent yang digunakan untuk meningkatkan kekentalan adalah garam natrium karboksimetilselulosa ( $\mathrm{Na}-\mathrm{CMC}$ ), natrium alginat, sukrosa, metilselulosa, asam alginat, asam hialuronat, PVP, dan 
xanthan gum. Bahan penstabil ditambahkan ke dalam formula untuk melindungi bahan obat atau vaksin saat proses coating atau pengeringan. Bahan yang dapat digunakan sebagai agen penstabil adalah glukosa, sukrosa, inulin, trehalosa, dan dekstran.5,21

Vaksin-vaksin yang telah dikembangkan secara in vivo menggunakan coated microneedle adalah influenza, herpes simplex virus, human papillomavirus (HPV), chikungunya virus, virus polio, hepatitis $\mathrm{C}$, hepatitis $\mathrm{B}$, rotavirus, measles, west nile virus, dan bacillus Calmette-Guérin. ${ }^{20}$

\section{Dissolving microneedle}

Dissolving microneedle dikembangkan dengan menggunakan polimer yang dapat larut pada kulit, sehingga jarum tajam dari microneedle tidak akan tertinggal saat patch dilepaskan. Bahan-bahan yang digunakan berupa bahan yang aman, inert, dan larut air seperti polimer dan gula yang akan larut saat diaplikasikan pada kulit. ${ }^{5}$

Kebanyakan pembuatan dissolving microneedle dengan cara cetakan mikron yang diisi pelarut, air sebagai pelarut biasa yang digunakan, kemudian diisi dengan polimer yang sudah larut atau lelehan polimer dan dibiarkan hingga mengering, disebut juga dengan polimerisasi monomer likuida in-situ dalam cetakan. Bahan-bahan yang dapat digunakan yaitu dextran, dextrin, chondroitin sulfat, gula yang sudah dilarutkan dengan air, PVP, PVA, dan PLGA. ${ }^{22-24}$

Penggunaan dissolving microneedle sebagai penghantar senyawa yang peka terhadap panas seperti protein dan antigen (vaksin) harus melalui tahap enkapsulasi dan pemadatan, sehingga tidak akan merusak aktivitasnya. Beberapa literatur menjelaskan bahwa kebanyakan dissolving microneedle membutuhkan waktu sekitar 5 menit untuk larut sepenuhnya. Oleh karena itu, microneedle didesain dengan bentuk seperti mata panah, sehingga dapat memungkinkan polimer dengan cepat terlepas dari tangkai jarum dan tetap tertanam pada kulit untuk berdisolusi. ${ }^{25}$

Penggunaan dissolving microneedle sangat biokompatibel dan tidak meninggalkan jarum pada kulit apabila terjadi kegagalan dapal melepaskan patch. Vaksin influenza, tetanus, measles, polio, HIV, malaria, hepatitis B, dan difteri juga sudah dikembangkan dengan dissolving microneedle secara in vivo. ${ }^{20}$

\section{Hollow microneedle}

Pada hollow microneedle terdapat saluran untuk mengalirkan formula seperti jarum konvensional. Formula dibuat dalam bentuk likuida, sehingga formula dapat mengalir ke dalam kulit melalui microneedle karena adanya tekanan. Beberapa metode telah dirancang untuk penghantaran cairan obat menggunakan hollow microneedle. Hollow microneedle biasanya digunakan menggunakan syringe untuk menginjeksikan formula. Akan tetapi, ada beberapa sistem terintegrasi dengan akuator. Aliran likuida pada hollow microneedle diatur dengan tekanan gas $\mathrm{CO}_{2}$, pegas, pompa syringe, pompa micro gear, piezo-electric micropump, dan a piezoelectric linear servo motor. ${ }^{5}$ 
Penggunaan hollow microneedle dalam administrasi vaksin, memungkinkan aplikasi formulasi vaksin pada area kulit yang lebih luas. Hal ini dapat menyebabkan bioavailabilitas yang lebih tinggi dan menginduksi antigen limfatik. ${ }^{20}$

\section{Penggunaan Microneedle Pada Vaksin}

Microneedle banyak digunakan dalam aplikasi penghantar vaksin melalui kulit. Kulit adalah target yang baik dalam pemberian vaksin dibandingkan dengan intramuskular vaksinasi. ${ }^{26}$ Pada kulit terdapat banyak antigen-presenting cells sebagai respon awal dalam mengenali antigen. ${ }^{7}$ Penggunaan microneedle sebagai penghantar vaksin dapat dilihat pada tabel 1.

Stabilitas vaksin pun perlu diperhatikan. Penyimpanan vaksin dalam waktu yang cukup lama tanpa perlu pendinginan tentunya akan memberikan keuntungan, terutama bagi negara berkembang. Saat proses coating dan juga proses enkapsulasi pada dissolving microneedle dapat merusak kestabilan vaksin. Namun, penambahan bahan penstabil, seperti trehalosa, untuk melindungi zat termolabil dapat mengatasi permasalahan ini. ${ }^{5}$

Studi stabilitas in vitro terhadap vaksin influenza yang berisi virus inaktif dengan coated microneedle yang disimpan pada suhu ruangan selama 1 bulan menunjukkan penurunan antigenisitas sebesar $20 \%$. Namun, studi in vivo pada mencit yang divaksin menggunakan formula microneedle tersebut memberikan respon igG yang sama dengan vaksinasi menggunakan coated microneedle yang baru. Coated microneedle dengan vaksin subunit virus influenza formulasi berbeda memberikan respon antibodi pada mencit setelah formula microneedle disimpan selama 6 bulan. Hasil tersebut memberikan respon yang sama dibandingkan formula microneedle yang baru dibuat. Studi stabilitas mengenai mekanistik terhadap coated microneedle vaksin influenza menunjukkan transformasi fase dan kristalisasi trehalosa pada lapisan microneedle. Transformasi fase khususnya kristalisasi trehalosa berhubungan sangat kuat dengan berkurangnya antigenisitas vaksin. Studi lain pun menunjukkan vaksin BCG pada coated microneedle kehilangan antigenisitas sebesar $30 \%$ setelah penyimpanan selama 7 minggu pada suhu ruang. ${ }^{27-29}$ Penurunan aktivitas antigen pada saat proses coating dapat dikarenakan adanya agregasi antigen virus. ${ }^{21}$

Stabilitas vaksin perlu divalidasi pada suhu dan periode waktu penyimpanan tertentu. Penentuan stabilitas vaksin digunakan untuk menjaga efikasi dan keamanannya. Beberapa penelitian menunjukkan bahwa penggunaan vaksin dengan microneedle memiliki potensi stabilitas dalam waktu yang lebih lama tanpa membutuhkan pendingin tambahan yang dapat meningkatkan biaya produksi. ${ }^{28,30,31}$

Tabel 1. Aplikasi microneedle pada vaksin

\begin{tabular}{|c|c|c|c|c|}
\hline No & Vaksin & Jenis & Formula & Hasil \\
\hline 1. & Influenza ${ }^{26}$ & $\begin{array}{c}\text { Coated } \\
\text { microneedle }\end{array}$ & $\begin{array}{l}\text { Na-CMC, surfaktan } \\
\text { (Lutrol F-68 NF), D-(+)- } \\
\text { trehalose dihidrat, }\end{array}$ & $\begin{array}{l}\text { Distribusi antigen yang } \\
\text { merata pada lapisan } \\
\text { dermal dan epidermal. }\end{array}$ \\
\hline
\end{tabular}




\begin{tabular}{|c|c|c|c|c|}
\hline & & & $\begin{array}{l}\text { influenza } \begin{array}{r}\text { virus-like } \\
\text { particle dalam buffer } \\
\text { fosfat }\end{array} \\
\end{array}$ & $\begin{array}{l}\text { Administrasi dengan } \\
\text { microneedle meningkatkan } \\
\text { igG dibandingkan dengan } \\
\text { rute intramuskular pada } \\
\text { tikus. }\end{array}$ \\
\hline 2. & $\begin{array}{l}\text { Antibodi } \\
\text { TNF- } \alpha\end{array}$ & $\begin{array}{l}\text { Dissolvable } \\
\text { microneedle }\end{array}$ & $\begin{array}{l}\text { Low viscosity } \mathrm{Na}-\mathrm{CMC} \text {, } \\
\text { anti-TNF- } \alpha\end{array}$ & $\begin{array}{l}\text { Meningkatkan efisiensi } \\
\text { penghantaran anti-TNF- } \\
\alpha \text { pada dermis kulit manusia } \\
\text { berdasarkan profil klinis. }\end{array}$ \\
\hline 3. & Polio $^{32}$ & $\begin{array}{l}\text { Dissolvable } \\
\text { microneedle }\end{array}$ & $\begin{array}{l}\text { Trehalose, } \\
\mathrm{Mg}(\mathrm{Cl})^{2} .6 \mathrm{H} 2 \mathrm{O}, \\
\text { monosodium glutamat, } \\
\text { sorbitol, virus polio } \\
\text { inaktif }\end{array}$ & $\begin{array}{l}\text { Meningkatkan netralisasi } \\
\text { antibodi yang dibandingkan } \\
\text { dengan vaksin likuid yang } \\
\text { diberikan secara } \\
\text { intramuskular. }\end{array}$ \\
\hline 4. & $\begin{array}{l}\text { Influenza } \\
(\mathrm{H} 5 \mathrm{~N} 1 \text { dan } \\
\mathrm{H} 1 \mathrm{~N} 1)^{33}\end{array}$ & $\begin{array}{l}\text { Dissolvable } \\
\text { microneedle }\end{array}$ & $\begin{array}{l}\text { PR8 (H1N1), Vac-3 } \\
\text { (H5N1), aquadest, } \\
\text { Hydroxyethyl starch, } \\
\text { polietilen tereftalat } \\
\text { (PET), kondroitin sulfat. }\end{array}$ & $\begin{array}{lr}\text { Vaksinasi } & \text { whole virus } \\
\text { particle (WVP) baik virus } \\
\text { H5N1 dan H1N1 dengan } \\
\text { dissolvabler microneedle } \\
\text { menunjukkan respon } \\
\text { antibodi r netralisasi } \\
\text { dibandingkan ran } \\
\text { pemberian secara subkutan } \\
\text { pada mencit. }\end{array}$ \\
\hline 5. & Covid-19 ${ }^{1}$ & $\begin{array}{l}\text { Dissolvable } \\
\text { microneedle }\end{array}$ & $\begin{array}{l}\text { Karboksimetil selulosa, } \\
\text { SARS-CoV-2-S1 }\end{array}$ & $\begin{array}{lr}\text { Peningkatan } & \text { antibodi } \\
\text { spesifik } & \text { antigen } \\
\text { dibandingkan } & \text { dengan } \\
\text { injeksi subkutan pada uji } \\
\text { pre klinik. }\end{array}$ \\
\hline 6. & $\mathrm{HPV}^{34}$ & $\begin{array}{c}\text { Hollow } \\
\text { microneedle }\end{array}$ & $\begin{array}{l}\mathrm{HPV} \quad \mathrm{E} 743-63 \quad \mathrm{SLP} ; \\
\mathrm{NH} 4 \mathrm{OH} ; 1,2-\text { dioleoyl-3- } \\
\text { trimethylammonium- } \\
\text { propane; 1,2- dioleoyl- } \\
\text { sn-glycero-3- } \\
\text { phosphocholine }\end{array}$ & $\begin{array}{l}\text { Respon sel } T \text { yang kuat } \\
\text { pada mencit dengan } \\
\text { menggunakan silica kapiler } \\
\text { microneedle. }\end{array}$ \\
\hline 7. & Difteri $^{35}$ & $\begin{array}{c}\text { Solid } \\
\text { microneedle }\end{array}$ & $\begin{array}{l}\text { Microneedle logam. } \\
\text { Formula vaksin: } \mathrm{N} \text { - } \\
\text { trimethyl chitosan, toksin } \\
\text { difteri, buffer karbonat, } \\
\text { buffer fosfat, natrium } \\
\text { klorida } 1 \% \text {. }\end{array}$ & 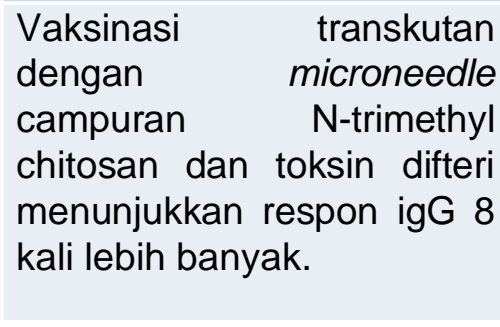 \\
\hline
\end{tabular}

\section{Desain dan Pengembangan Vaksin COVID-19 dengan Microneedle}

Virus corona - SARS-CoV, SARS-CoV-2, dan MERS-CoV- memiliki protein spike (S) pada bagian permukaan envelope. Protein $S$ tersebut yang dijadikan taget dalam pengembangan vaksin COVID-19. Antibodi netralisasi merupakan hal penting dalam sistem imun untuk melawan infeksi virus. ${ }^{2}$ 
Penelitian yang dilakukan oleh Kim et al., (2014) menunjukkan bahwa vaksin SARSCoV-S1 dan MERS-S1 dengan vektor adenoviral dapat meningkatkan induksi antibodi netralisasi terhadap virus corona hidup dibandingkan dengan menggunakan komponen S1 sendiri - berdasarkan uji menggunakan enzyme-linked immunosorbent assay (ELISA). Studi lain memperlihatkan hasil bahwa pada fase pemulihan, receptor binding domains (RBD) virus SARS (SARS-CoV) yang ditunjukkan oleh protein subunit S1 memberikan respon kuat terhadap antisera dari pasien SARS. ${ }^{36}$

Selanjutnya pada penelitian Kim et al., (2020) dalam mengembangkan vaksin MERSCoV-S1 menggunakan metode dissolving microneedle dengan polimer Na-CMC. Pemberian vaksin menggunakan microneedle memberikan kadar antigen spesifik igG yang lebih tinggi secara signifikan dibandingkan dengan pemberian injeksi subkutan. Hasil immunogenisitas vaksin MERS-CoV tanpa adjuvant menjadikan vaksin tersebut sebagai kandidat dalam uji klinik selanjutnya. Respon antibodi spesifik MERS-S1 dan penghantar vaksin menggunakan microneedle dapat diaplikasikan dalam pengembangan dan desain vaksin COVID-19. Selain itu, telah diteliti dalam uji pre klinik SARS-CoV-2-S1 menggunakan microneedle menunjukkan hasil yang sama dengan MERS-S1. Secara statistik, vaksin microneedle SARS-CoV-2-S1 dapat meningkatkan antibodi spesifik antigen dalam waktu dua minggu dibandingkan dengan respon preimunisasi dan setelah satu minggu pemberian vaksin.

Peningkatan antibodi spesifik tersebut dikarenakan stress mekanikal yang diberikan oleh microneedle. Stress mekanikal dari microneedle dapat menginduksi secara lokal respon innate immune. Hal tersebut digunakan sebagai adjuvant fisik dalam meningkatkan imun adaptif spesifik antigen. ${ }^{37}$

\section{KESIMPULAN}

Pengembangan dan desain vaksin dalam upaya pencegahan penyebaran COVID-19 masih terus dilakukan hingga saat ini. Dalam pengaplikasiannya, sebagian besar vaksin diberikan menggunakan jarum yang tidak bisa digunakan dengan mudah dan dapat dan memberikan kesan tidak nyaman pada pasien. Microneedle memiliki bentuk yang kecil dan didesain tanpa menggunakan peralatan khusus dalam aplikasinya. Sehingga, dalam penggunaannya dapat dilakukan sendiri tanpa menimbulkan rasa sakit. Selain itu, melalui mekanisme stress mekanikal dari microneedle dapat digunakan sebagai adjuvant dalam meningkatkan respon imun. Melalui model pre-klinik, terhadap hewan uji, penghantaran vaksin menggunakan microneedle mendemostrasikan keamanan dan peningkatan imunogenisitas. Beberapa studi klinik penggunaan vaksin dengan microneedle juga sudah dilakukan dan memberikan respon yang sama dengan uji preklinik walaupun masih membutuhkan uji-uji pendukung lainnya. Dengan demikian, fiturfitur tersebut memberikan keuntungan yang mendukung microneedle dalam penggunaannya sebagai penghantar vaksin COVID-19. Berdasarkan paparan yang telah dijelaskan pada review ini, penggabungan metode bioteknologi dengan teknologi baru dalam strategi penghantaran vaksin tersebut diharapkan dapat memberikan pelindungan secara global dari persebaran virus COVID-19. 


\section{Ucapan Terimakasih}

Penulis panjatkan rasa syukur kepada Allah SWT karena rahmat dan karunia-Nya penulis dapat menyelesaikan review article ini. Penulis juga mengucapkan terima kasih kepada dosen mata kuliah Metodologi Riset dan Biostatistik yang telah memberikan ilmu yang bermanfaat, serta kepada dosen pembimbing yang telah bersedia meluangkan waktunya untuk membimbing, memberikan kritik dan saran, juga perbaikan dalam penulisan review article ini.

\section{DAFTAR PUSTAKA}

1. Kim E, Erdos G, Huang S, Kenniston TW, Balmert SC, Carey CD, et al. Microneedle array delivered recombinant coronavirus vaccines: Immunogenicity and rapid translational development. EBioMedicine [Internet]. 2020;000:102743. Available from: https://doi.org/10.1016/j.ebiom.2020.102743

2. Zhou P, Yang X Lou, Wang XG, Hu B, Zhang L, Zhang W, et al. A pneumonia outbreak associated with a new coronavirus of probable bat origin. Nature [Internet]. 2020;579(7798):270-3. Available from: http://dx.doi.org/10.1038/s41586-020-2012-7

3. Zaki AM, Van Boheemen S, Bestebroer TM, Osterhaus ADME, Fouchier RAM. Isolation of a novel coronavirus from a man with pneumonia in Saudi Arabia. N Engl J Med. 2012;367(19):1814-20.

4. Ahmed SF, Quadeer AA, McKay MR. Preliminary identification of potential vaccine targets for the COVID-19 Coronavirus (SARS-CoV-2) Based on SARSCoV Immunological Studies. Viruses. 2020;12(3).

5. Kim YC, Park JH, Prausnitz MR. Microneedles for drug and vaccine delivery. Adv Drug Deliv Rev [Internet]. 2012;64(14):1547-68. Available from: http://dx.doi.org/10.1016/j.addr.2012.04.005

6. Master AM, Rodriguez ME, Kenney ME, Oleinick NL, Sen Gupta A. Delivery of the photosensitizer Pc 4 in PEG-PCL micelles for in vitro PDT studies. J Pharm Sci. 2010;99(5):2386-2398.

7. Balmert SC, Carey CD, Falo GD, Sethi SK, Erdos G, Korkmaz E, et al. Dissolving undercut microneedle arrays for multicomponent cutaneous vaccination. J Control Release [Internet]. 2020;317:336-46. Available from: https://doi.org/10.1016/j.jconrel.2019.11.023

8. Korkmaz E, Friedrich EE, Ramadan MH, Erdos G, Mathers AR, Burak Ozdoganlar $\mathrm{O}$, et al. Therapeutic intradermal delivery of tumor necrosis factoralpha antibodies using tip-loaded dissolvable microneedle arrays. Acta Biomater [Internet]. 2015;24:96-105. Available from: http://dx.doi.org/10.1016/j.actbio.2015.05.036

9. Suh H, Shin J, Kim Y-C. Microneedle patches for vaccine delivery. Clin Exp Vaccine Res. 2014;3(1):42. 
10. Woo PCY, Lau SKP, Lam CSF, Lau CCY, Tsang AKL, Lau JHN, et al. Discovery of Seven Novel Mammalian and Avian Coronaviruses in the Genus Deltacoronavirus Supports Bat Coronaviruses as the Gene Source of Alphacoronavirus and Betacoronavirus and Avian Coronaviruses as the Gene Source of Gammacoronavirus and Deltacoronavi. J Virol. 2012;86(7):3995-4008.

11. NCIRD. Coronavirus [Internet]. 2020 [cited 2020 Jun 4]. Available from: https://www.cdc.gov/coronavirus/types.html

12. Lau SKP, Li KSM, Huang Y, Shek C-T, Tse H, Wang M, et al. Ecoepidemiology and Complete Genome Comparison of Different Strains of Severe Acute Respiratory Syndrome-Related Rhinolophus Bat Coronavirus in China Reveal Bats as a Reservoir for Acute, Self-Limiting Infection That Allows Recombination Events. J Virol. 2010;84(6):2808-19.

13. Jiaming L, Yanfeng $\mathrm{Y}$, Yao D, Yawei $\mathrm{H}$, Linlin $\mathrm{B}$, Baoying $\mathrm{H}$, et al. The recombinant $\mathrm{N}$-terminal domain of spike proteins is a potential vaccine against Middle East respiratory syndrome coronavirus (MERS-CoV) infection. Vaccine [Internet]. 2017;35(1):10-8. Available from: http://dx.doi.org/10.1016/j.vaccine.2016.11.064

14. Chen HW, Huang CY, Lin SY, Fang ZS, Hsu CH, Lin JC, et al. Synthetic virus-like particles prepared via protein corona formation enable effective vaccination in an avian model of coronavirus infection. Biomaterials [Internet]. 2016;106:111-8. Available from: http://dx.doi.org/10.1016/j.biomaterials.2016.08.018

15. McLenon J, Rogers MAM. The fear of needles: A systematic review and metaanalysis. Vol. 75, Journal of Advanced Nursing. 2019. 30-42 p.

16. Hoang MT, Ita KB, Bair DA. Solid microneedles for transdermal delivery of amantadine hydrochloride and pramipexole dihydrochloride. Pharmaceutics. 2015;7(4):379-96.

17. Bariya SH, Gohel MC, Mehta TA, Sharma OP. Microneedles: An emerging transdermal drug delivery system. J Pharm Pharmacol. 2012;64(1):11-29.

18. Chong RHE, Gonzalez-Gonzalez E, Lara MF, Speaker TJ, Contag CH, Kaspar $\mathrm{RL}$, et al. Gene silencing following siRNA delivery to skin via coated steel microneedles: In vitro and in vivo proof-of-concept. J Control Release [Internet]. 2013;166(3):211-9. Available from: http://dx.doi.org/10.1016/j.jconrel.2012.12.030

19. Donnelly RF, Majithiya R, Singh TRR, Morrow DIJ, Garland MJ, Demir YK, et al. Design, optimization and characterisation of polymeric microneedle arrays prepared by a novel laser-based micromoulding technique. Pharm Res. $2011 ; 28(1): 41-57$.

20. Marshall S, Sahm LJ, Moore AC. The success of microneedle-mediated vaccine delivery into skin. Hum Vaccines Immunother. 2016;12(11):2975-83.

21. 21. Kim YC, Quan FS, Compans RW, Kang SM, Prausnitz MR. Formulation and coating of microneedles with inactivated influenza virus to improve vaccine stability and immunogenicity. J Control Release [Internet]. 2010;142(2):187-95. Available from: http://dx.doi.org/10.1016/j.jconrel.2009.10.013 
22. Ito $\mathrm{Y}$, Hasegawa R, Fukushima K, Sugioka N, Takada K. Self-dissolving micropile array chip as percutaneous delivery system of protein drug. Biol Pharm Bull. 2010;33(4):683-90.

23. Ito $\mathrm{Y}$, Maeda T, Fukushima K, Sugioka N, Takada K. Permeation enhancement of ascorbic acid by self-dissolving micropile array tip through rat skin. Chem Pharm Bull. 2010;58(4):458-63.

24. Raphael AP, Prow TW, Crichton ML, Chen X, Fernando GJP, Kendall MAF. Targeted, needle-free vaccinations in skin using multilayered, densely-packed dissolving microprojection arrays. Small. 2010;6(16):1785-93.

25. Chu LY, Prausnitz MR. Separable arrowhead microneedles. J Control Release [Internet]. 2011;149(3):242-9. Available from: http://dx.doi.org/10.1016/j.jconrel.2010.10.033

26. Quan FS, Kim YC, Compans RW, Prausnitz s MR, Kang SM. Dose sparing enabled by skin immunization with influenza virus-like particle vaccine using microneedles. J Control Release [Internet]. 2010;147(3):326-32. Available from: http://dx.doi.org/10.1016/j.jconrel.2010.07.125

27. Kim YC, Quan FS, Compans RW, Kang SM, Prausnitz MR. Stability kinetics of influenza vaccine coated onto microneedles during drying and storage. Pharm Res. 2011;28(1):135-44.

28. Choi HJ, Yoo DG, Bondy BJ, Quan FS, Compans RW, Kang SM, et al. Stability of influenza vaccine coated onto microneedles. Biomaterials [Internet]. 2012;33(14):3756-69. Available from: http://dx.doi.org/10.1016/j.biomaterials.2012.01.054

29. Park K. Improving the reach of vaccines to low-resource regions with a needlefree vaccine delivery device and long-term thermostabilization. J Control Release [Internet]. 2011;152(3):329.

Available

from: http://dx.doi.org/10.1016/j.jconrel.2011.05.015

30. Rouphael NG, Paine M, Mosley R, Henry S, McAllister D V., Kalluri H, et al. The safety, immunogenicity, and acceptability of inactivated influenza vaccine delivered by microneedle patch (TIV-MNP 2015): a randomised, partly blinded, placebo-controlled, phase 1 trial. Lancet. 2017;390(10095):649-58.

31. Mistilis MJ, Joyce JC, Esser ES, Skountzou I, Compans RW, Bommarius AS, et al. Long-term stability of influenza vaccine in a dissolving microneedle patch. Drug Deliv Transl Res. 2017;7(2):195-205.

32. Donadei A, Kraan H, Ophorst O, Flynn O, O'Mahony C, Soema PC, et al. Skin delivery of trivalent Sabin inactivated poliovirus vaccine using dissolvable microneedle patches induces neutralizing antibodies. J Control Release [Internet]. 2019;311-312(August):96-103. Available from: https://doi.org/10.1016/j.jconrel.2019.08.039 
33. Nakatsukasa A, Kuruma K, Okamatsu M, Hiono T, Suzuki M, Matsuno K, et al. Potency of whole virus particle and split virion vaccines using dissolving microneedle against challenges of $\mathrm{H} 1 \mathrm{~N} 1$ and $\mathrm{H} 5 \mathrm{~N} 1$ influenza viruses in mice. Vaccine [Internet]. 2017;35(21):2855-61. Available from: http://dx.doi.org/10.1016/j.vaccine.2017.04.009

34. van der Maaden K, Heuts J, Camps M, Pontier M, Terwisscha van Scheltinga A, Jiskoot $W$, et al. Hollow microneedle-mediated micro-injections of a liposomal HPV E743-63 synthetic long peptide vaccine for efficient induction of cytotoxic and T-helper responses. J Control Release [Internet]. 2018;269:347-54. Available from: http://dx.doi.org/10.1016/j.jconrel.2017.11.035

35. Bal SM, Ding Z, Kersten GFA, Jiskoot W, Bouwstra JA. Microneedle-based transcutaneous immunisation in mice with $n$-trimethyl chitosan adjuvanted diphtheria toxoid formulations. Pharm Res. 2010;27(9):1837-47.

36. Kim E, Okada K, Kenniston T, Raj VS, AlHajri MM, Farag EABA, et al. Immunogenicity of an adenoviral-based Middle East Respiratory Syndrome coronavirus vaccine in BALB/c mice. Vaccine [Internet]. 2014;32(45):5975-82. Available from: http://dx.doi.org/10.1016/j.vaccine.2014.08.058

37. Depelsenaire ACI, Meliga SC, Mcneilly CL, Pearson FE, Coffey JW, Haigh OL, et al. Colocalization of cell death with antigen deposition in skin enhances vaccine immunogenicity. J Invest Dermatol [Internet]. 2014;134(9):2361-70. Available from: http://dx.doi.org/10.1038/jid.2014.174 